\title{
KONTRIBUSI MEDIA TELEVISI LOKAL DALAM MENYOSIALISASIKAN PROGRAM REVOLUSI MENTAL
}

\author{
Dida Dirgahayu ${ }^{1}$, Risa Sunarsi ${ }^{2}$ \\ 1,2Balai Pengkajian dan Pengembangan Komunikasi dan Informatika (BPPKI) Bandung \\ Jl. Pajajaran No. 88 Bandung, Jawa Barat, Indonesia \\ No. Telp./HP: ${ }^{1} 081573761965,{ }^{2} 081214624374$ \\ E-mail: ${ }^{1}$ dirgahayu1965@yahoo.co.id, ${ }^{2}$ risastoni@gmail.com
}

Naskah diterima tanggal 14 Desember 2016, direvisi tanggal 3 Mei 2017, disetujui tanggal 12 Mei 2017

\section{LOCAL TELEVISION MEDIA CONTRIBUTION IN SOCIALIZING MENTAL REVOLUTION PROGRAM}

\begin{abstract}
Mental revolution is the eight program stated in the priority agenda of Nawacita, the revolution of national character and the action plan of Priority Program-9 (Quick Wins). Specifically, mental revolution comes into Medium Term Development Plan (RPJM) 2015-2019 Ministry of Information and Communication Technology Republic of Indonesia (RI), that is to consistently implement Law No. 14 of 2008 on Public Information Openness. One strategy is the provision of quality public information content to enhance the nations' intelligence and personality development and their social environment and public campaigns related to mental revolution. This research uses the descriptive qualitative method to discover the contribution of local television media in socializes mental revolution program. The location of research in TV Kuningan at Kuningan Regency, Cirebon TV at Cirebon Regency, and SMTV at Sumedang Regency. The result shows that the local television stations are directly or indirectly participate in socializing mental revolution program through the created broadcast program. The contribution of local television broadcast is effective and efficient to have a role as media of socialization by its function. Mental revolution has done and explored by the local television stations that are created based on variety and innovative local idea and viewpoint.
\end{abstract}

Keywords: contributions, local television, socialization, mental revolution.

\begin{abstract}
Abstrak. Revolusi mental merupakan program kedelapan yang tertuang dalam agenda prioritas Nawacita yaitu revolusi karakter bangsa dan action plan Program Prioritas-9 (Quick Wins). Secara spesifik revolusi mental menjadi RPJM 2015-2019 Kementerian Komunikasi dan Informatika (Kemkominfo) Republik Indonesia (RI), yaitu melaksanakan secara konsisten UU No. 14 Tahun 2008 tentang Keterbukaan Informasi Publik. Salah satu strateginya adalah penyediaan konten informasi publik berkualitas untuk meningkatkan kecerdasan dan pengembangan kepribadian bangsa dan lingkungan sosialnya serta kampanye publik terkait revolusi mental. Metode penelitian ini adalah deskriptif kualitatif untuk mengetahui tentang kontribusi media televisi lokal dalam menyosialisasikan program revolusi mental. Lokasi penelitian di TV Kuningan Kabupaten Kuningan, Cirebon TV Kabupaten Cirebon, dan SMTV Kabupaten Sumedang. Hasil penelitian menunjukkan stasiun televisi lokal secara langsung atau tidak langsung telah ikut serta menyosialisasikan program revolusi mental melalui program siaran yang dibuat. Kontribusi siaran televisi lokal efektif dan efisien untuk berperan sebagai media sosialisasi sesuai dengan fungsi yang dimilikinya. Revolusi mental telah dilakukan dan dieksplorasi oleh stasiun televisi lokal yang dibuat berdasarkan pemikiran dan sudut pandang lokal yang variatif dan inovatif.
\end{abstract}

Kata kunci: kontribusi, televisi lokal, sosialisasi, revolusi mental.

DOI: $10.20422 / j p k . v 20 i 2.130$ 


\section{PENDAHULUAN}

Presiden Republik Indonesia, Ir. H. Joko Widodo menyatakan, nation building tidak mungkin maju kalau sekadar mengandalkan perombakan institusional tanpa melakukan perombakan manusianya atau karakter mereka yang menjalankan sistem ini. Sehebat apapun kelembagaan yang diciptakan, selama ditangani oleh manusia dengan salah kaprah tidak akan membawa kesejahteraan.

Sejarah Indonesia merdeka penuh dengan contoh di mana salah pengelolaan (mismanagement) negara telah membawa bencana besar nasional. Sudah saatnya Indonesia melakukan tindakan korektif dengan mencanangkan revolusi mental, menciptakan paradigma, budaya politik, dan pendekatan nation building baru yang lebih manusiawi, sesuai dengan budaya nusantara, bersahaja, dan berkesinambungan. Melakukan konsep Trisakti dengan tiga pilarnya, yaitu: Indonesia yang berdaulat secara politik, Indonesia yang mandiri secara ekonomi, dan Indonesia yang berkepribadian secara sosial budaya.

Media massa dalam menjalankan aktivitasnya secara langsung maupun tidak langsung akan menjalankan fungsinya seperti yang diamanatkan oleh RPJM 2015-2019 Kementerian Komunikasi dan Informatika (Kemkominfo) RI Bidang Politik dan Komunikasi, yaitu karya jurnalistik yang berkualitas untuk meningkatkan kecerdasan dan pengembangan kepribadian bangsa dan lingkungan sosialnya, serta kampanye publik terkait revolusi mental.

Realitasnya, sedikit sekali tulisan maupun siaran pada media massa yang mengangkat program revolusi mental, padahal pers khususnya surat kabar dan televisi sebagai akses informasi publik dapat berperan dalam menyosialisasikan program revolusi mental sehingga dapat lebih dikenal dan pada akhirnya dapat menimbulkan partisipasi nyata dari masyarakat. Berdasarkan kondisi dan kerangka berpikir di atas, maka penelitian "Kontribusi Media Televisi Lokal dalam Menyosialisasikan Program Revolusi Mental“" penting dilakukan untuk memberikan gambaran tentang bagaimana peran dan kontribusi yang bisa dilakukan oleh media massa sebagai akses informasi publik dalam menyosialisasikan program revolusi mental.

Penelitian memetakan tentang kondisi saat ini stasiun televisi lokal dilihat dari program siaran yang sudah ada dan kontribusi yang dapat dilakukan ke depan melalui siaran yang dibuat dalam upaya menyosialisasikan program revolusi mental. Permasalahannya adalah bagaimana kontribusi media televisi lokal dalam menyosialisasikan program revolusi mental?

Tujuan penelitian adalah untuk menjawab permasalahan yaitu kontribusi keikutsertaan dan pemikiran pengelola stasiun televisi lokal dalam menyosialisasikan program revolusi mental dan membuat model kemitraan antara pemerintah dengan stasiun TV lokal.

Manfaat penelitian ini adalah untuk memberikan kajian ilmiah kepada Kementerian Komunikasi dan Informatika (Kemkominfo) RI, sebagai dasar untuk membuat program pengembangan media televisi lokal. Hasil penelitian ini diharapkan juga memberikan model kemitraan antara pemerintah dalam hal ini Kementerian Komunikasi dan Informatika RI, khususnya Direktorat Jenderal Informasi dan Komunikasi Publik (IKP) Kemkominfo RI, dan Komisi Penyiaran Indonesia (KPI), pemerintah daerah dengan pengelola stasiun televisi lokal di daerah sebagai media diseminasi informasi dalam upaya menyosialisasikan program revolusi mental.

\section{LANDASAN KONSEP}

\section{Kajian Terdahulu}

Data dan kajian dari Dr. Dedeh Fardiah, M.Si, Ketua Komisi Penyiaran Indonesia (KPID) Provinsi Jawa Barat menunjukkan bahwa pada akhir tahun 2015, KPID Jawa Barat menerbitkan buku Direktori Penyiaran Jawa Barat yang berisi data tentang eksistensi lembaga penyiaran yang legal atau berizin di Jawa Barat. Buku ini dapat menjadi referensi bagi pihak-pihak yang berkepentingan, baik 
pemerintah, pemerintah daerah, perusahaanperusahaan yang ada di Jawa Barat, maupun seluruh stakeholder penyiaran. Mereka dapat memanfaatkan potensi besar lembaga penyiaran di Jawa Barat untuk berkontribusi dan berpartisipasi dalam upaya penguatan keberadaan lembaga penyiaran di Jawa Barat.

Untuk meningkatkan penguatan lembaga penyiaran di Jawa Barat maka perlu adanya kajian yang mendalam tentang beberapa tema yang akan memperkuat kelembagaan lembaga penyiaran sehingga akan berguna bagi penyiaran lokal, pemerintah, komisi penyiaran sebagai regulator dan masyarakat sebagai pemirsa media penyiaran lokal.

Kontribusi berasal dari Bahasa Inggris yaitu contribute, contribution, maknanya adalah keikutsertaan, keterlibatan, melibatkan diri maupun sumbangan. Kontribusi dapat berupa materi atau tindakan. Kontribusi dalam pengertian sebagai tindakan yaitu berupa perilaku yang dilakukan oleh individu yang kemudian memberikan dampak baik positif maupun negatif terhadap pihak lain. Dengan kontribusi berarti individu tersebut juga berusaha meningkatkan efisiensi dan efektivitas hidupnya. Hal ini dilakukan dengan cara menajamkan posisi perannya, sesuatu yang kemudian mejadi bidang spesialis, agar lebih tepat sesuai dengan kompetensi. Kontribusi dapat diberikan dalam berbagai bidang yaitu pemikiran, kepemimpinan, profesionalisme, finansial, dan lainnya (Ahira dalam Suprastowo, 2014).

\section{Kontribusi Media Massa}

Peran media massa dalam berbagai aspek kehidupan sosial masyarakat modern semakin besar. Hal itu tampak pada usaha penggunaan media massa untuk mempercepat proses perubahan sosial di negara-negara berkembang ataupun penggunaannya untuk kampanye politik, advertensi, dan propaganda (Subiakto \& Ida, 2012).

Disebabkan sifat dan faktanya bahwa pekerjaan media massa adalah menceritakan peristiwa-peristiwa, maka seluruh isi media adalah realitas yang telah dikonstruksikan (constructed reality). Isi media pada hakikatnya adalah hasil rekonstruksi realitas dengan bahasa sebagai perangkat dasarnya, sedangkan bahasa bukan saja alat untuk merepresentasikan realitas, namun juga bisa menentukan relief seperti apa yang akan diciptakan oleh bahasa tentang realitas (Sobur, 2002).

Televisi sebagai akses informasi publik adalah media massa yang mempunyai sifat yang dapat memenuhi kebutuhan dan keinginan khalayak, bersifat audio visual (didengar dan dilihat), menggambarkan kenyataan dan dapat langsung menyajikan peristiwa yang sedang terjadi ke setiap rumah para pemirsa dimanapun mereka berada (Ardianto, Komala \& Karlinah, 2004). Jurnalistik merupakan media massa sebagian informasi yang diakses publik. Jurnalistik secara etimologis berasal dari kata journ. Secara sederhana jurnalistik diartikan sebagai kegiatan yang berhubungan dengan pencatatan atau pelaporan setiap hari (Sumadiria, 2005).

Dalam leksikon komunikasi dirumuskan, jurnalistik adalah pekerjaan mengumpulkan, menulis, menyunting, dan menyebarkan berita dalam karangan untuk surat kabar, majalah, dan media massa lainnya seperti radio dan televisi (Kridalaksana dalam Sumadiria, 2005).

\section{Pesan Politik Nawacita dan Revolusi Mental}

Nawacita digagas oleh Presiden Joko Widodo untuk menunjukkan prioritas jalan perubahan menuju Indonesia yang berdaulat secara politik, serta mandiri dalam bidang ekonomi dan berkepribadian dalam kebudayaan, yaitu: (1) Menghadirkan kembali negara untuk melindungi segenap bangsa dan memberikan rasa aman pada seluruh warga negara; (2) Membuat pemerintah tidak absen dengan membangun tata kelola pemerintahan yang bersih, efektif, demokratis, dan terpercaya; (3) Membangun Indonesia dari pinggiran dengan memperkuat daerah-daerah dan desa dalam kerangka negara kesatuan; (4) Menolak negara lemah dengan melakukan reformasi sistem dan penegakan hukum yang bebas korupsi, bermartabat, dan terpercaya; (5) Meningkatkan kualitas hidup manusia Indonesia melalui peningkatan kualitas 
pendidikan dan pelatihan dengan program "Indonesia Pintar"; (6) Meningkatkan produktivitas rakyat dan daya saing di pasar internasional sehingga bangsa Indonesia bisa maju dan bangkit bersama bangsa-bangsa Asia lainnya; (7) Mewujudkan kemandirian ekonomi dengan menggerakkan sektor-sektor strategis ekonomi domestic; (8) Melakukan revolusi karakter bangsa melalui kebijakan penataan kembali kurikulum pendidikan nasional dengan mengedepankan aspek pendidikan kewarganegaraan, pengajaran sejarah pembentukan bangsa, nilai-nilai patriotisme dan cinta tanah air, semangat bela negara dan budi pekerti; (9) Memperteguh kebhinnekaan dan memperkuat restorasi sosial Indonesia melalui kebijakan memperkuat pendidikan kebhinnekaan dan menciptakan ruang-ruang dialog antarwarga.

Menurut Presiden RI, Ir.H. Joko Widodo, dalam pembangunan bangsa, saat ini kita cenderung menerapkan prinsip-prinsip paham liberalisme yang jelas tidak sesuai dan kontradiktif dengan nilai, budaya, dan karakter bangsa Indonesia. Sudah saatnya Indonesia melakukan tindakan korektif, tidak dengan menghentikan proses reformasi yang sudah berjalan, tetapi dengan mencanangkan revolusi mental menciptakan paradigma, budaya, politik, dan pendekatan nation building baru yang lebih manusiawi, sesuai dengan budaya nusantara, bersahaja, dan berkesinambungan (Wedhaswary, 2015).

Tujuh butir program gerakan nasional revolusi mental Indonesia Baru: (1) Negara harus hadir di tengah-tengah masyarakat; (2) Indonesia bukan sekedar negara kaya, tetapi juga serba bias, bisa mandiri; (3) Indonesia adalah teladan dalam hal toleransi dan pembauran karena perbedaan adalah kekayaan bangsa; (4) Indonesia harus bisa menggenggam dunia; (5) Indonesia adalah negara yang makmur di atas pondasi ekonomi kerakyatan; (6) Indonesia adalah bangsa terhormat dan tidak bersedia menjadi budak bangsa lain; (7) Indonesia adalah bangsa yang membanggakan dan penuh prestasi, Indonesia bukan bangsa rendah diri (Wedhaswary, 2015).
Melakukan revolusi mental dapat dilaksanakan melalui konsep Trisakti yang pernah diutarakan Bung Karno dalam pidatonya tahun 1963 dengan tiga pilarnya, yaitu: (1) Indonesia yang berdaulat secara politik; (2) Indonesia yang mandiri secara ekonomi; (3) Indonesia yang berkepribadian secara sosial-budaya.

Dalam Rencana Jangka Menengah Sektor Komunikasi dan Informatika 20152019 Kementerian Komunikasi dan Informatika tertulis bahwa komunikasi memegang peranan penting dalam pembentukan mental bangsa Indonesia di masa yang akan datang. Kehadiran media massa baik real space maupun cyberspace sangat berpengaruh terhadap budaya masyarakat Indonesia, maka diperlukan suatu kondisi dan ekosistem media massa untuk membentuk komunikasi yang memberikan efek baik bagi bangsa dan negara Indonesia (Kementerian Komunikasi dan Informatika, 2015).

\section{METODE PENELITIAN}

Penelitian ini menggunakan metode deskriptif kualitatif, sumber dan jenis utama dalam penelitian kualitatif ini adalah jawaban dari para informan, yang terdiri dari pemilik stasiun televisi lokal dan penanggungjawab program siaran di: (1) TV Kuningan Kabupaten Kuningan, (2) TV Cirebon Kabupaten Cirebon, (3) SMTV Sumedang Kabupaten Sumedang. Informan dipilih secara purposive. Alasan pemilihan sampel penelitian adalah berdasarkan data awal dinilai mempunyai program siaran yang mencerminkan makna revolusi mental. Sumber data sekunder mempergunakan literatur atau kepustakaan.

Teknik pengumpulan data dilakukan melalui wawancara terbuka dan terstruktur mempergunakan panduan wawancara. Metode analisis data deskriptif, menyusun secara sistematis data, catatan lapangan, dan dokumentasi. 


\section{HASIL DAN PEMBAHASAN}

\section{Cirebon TV}

Pemilik Cirebon TV adalah Ir. Toto Sunanto, beralamat di Jl. Raya Kriyan Timur No. 3, Pegambiran, Lemahwungkuk, Cirebon. Pemilik telah menjadi anggota dalam organisasi Asosiasi TV Lokal wilayah III Cirebon. Badan hukum Cirebon TV adalah PT. Pelangi Raya Televisi, nama di udara: "Cirebon TV Kudu Weruh". No.IPP: No.196/M.KOMINFO/8/2008 tanggal 20 Agustus 2008, izin siar tanggal 7 Januari 2010. Nama station manager: Sutodi Bintang. Alamat stasiun televisi: Jl. Raya Kriyan No. 3, Pegambiaran, Lemahwungkuk, Cirebon, 45113. Nomor telepon Cirebon TV: (0231) 3785029, Fax: (0231) 20247826, E-mail: pelangiraya.cirebontv@gmail.com. Frekuensi channel: 33 UHF, wilayah jangkauan siaran: Indramayu, Kuningan, Malajengka, Brebes, Sumedang, Subang, Tegal, Slawi, Pemalang, dan Bumi Ayu.

Latar belakang mendirikan Cirebon TV karena belum terakomodirnya informasiinformasi dan budaya lokal pada stasiun televisi nasional, banyak potensi masyarakat di daerah yang belum terekspose media. Mengangkat potensi lokal melalui siaran lokal. Cirebon TV menjadi televisi lokal pertama yang ada di Cirebon, dan mendapatkan Penghargaan Kategori "Budaya Tradisi KPID Jabar Tahun 2012.

\section{Kontribusi Cirebon TV dalam Menyosialisasikan Program Revolusi Mental}

Pemilik siaran Cirebon TV memahami Nawacita pemerintah sebagai arahan menuju kedaulatan politik, kemandirian ekonomi dan kepribadian memelihara budaya sendiri, melalui tindakan kebijakan dan implementasi kegiatan di lingkungan masing-masing, baik di pemerintahan atau lembaga dan institusi lainnya. Cirebon TV sebagai institusi yang bergerak di bidang penyiaran berperan serta membuka dialog baik kepada pemerintah maupun masyarakat yang dikemas dalam siaran atau kegiatan lainnya. Kalau dulu mental itu dibentuk melalui tahapan penataran P4 (Pedoman, Penghayatan, Pengamalan
Pancasila), sekarang diprogramkan dalam Nawacita dan Revolusi Mental.

Pemahaman tentang kearifan lokal sebagai tradisi dalam berbagai aspek kehidupan khususnya aspek budaya, masyarakat Cirebon mempunyai tata cara berbeda dengan komunitas lainnya yang merupakan kekayaan budaya bangsa. Cirebon TV media televisi lokal berperan sebagai media diseminasi informasi tentang program revolusi mental dalam konteks bangsa yang punya harga diri dan percaya diri akan kekayaan jati dirinya, televisi lokal merupakan salah satu ruang yang dapat dimanfaatkan untuk menyosialisasikan melalui program siaran.

Kebijakan Cirebon TV mengarahkan melalui program siaran, berkontribusi menyosialisasikan program revolusi mental bersinergikan dengan asas program siaran dan jadwal acara Cirebon TV. Di antaranya dalam salah satu asas program yaitu reality, yang isi dan kemasan program mengutamakan bahan baku yang bersumber dari realita kehidupan sehari-hari. Sosialisasi program revolusi mental bisa diprogramkan dalam acara unggulan, yaitu talkshow, bincang-bincang, dan program acara liputan khusus (lipsus).

Sosialisasi program revolusi mental melalui media televisi lokal dipandang efektif karena memiliki kedekatan dengan komunitasnya. Efektif karena dikemas dalam program siaran seperti bincang-bincang dan lipsus yang cukup diminati pemirsa karena dalam bincang-bincang menghadirkan tokoh dari kalangan masyarakat maupun eksekutif yang jadi panutan masyarakat. Selain efektif juga efisien, sosialisasi tidak perlu mengalokasikan dana konsumsi atau gedung pertemuan untuk menghadirkan orang, kalau pemerintah memiliki dana sosialisasi hanya cukup untuk membayar durasi biaya produksi siaran.

Kontribusi bisa diberikan oleh Cirebon TV sesuai fungsi informasi sosialisasi yang dapat dikemas dalam acara kudu weruh dan liputan khusus dengan dilandasi misi menyediakan informasi positif dan seimbang sesuai fungsi pendidikan komunikasi terbuka dan demokratis, setiap acara disajikan dengan nuansa edukatif, inspiratif, disajikan dalam 
konten lokal yang variatif, contoh: acara Hidup Indah bersama Buya (pendidikan agama), Pelangi Budaya (pendidikan), sebagai bagian dari tujuan mencerdaskan masyarakat Cirebon dan sekitarnya.

Sesuai fungsi hiburan di mana asas posisi Cirebon TV sebagai TV hiburan, budaya, dan informasi, diformulasikan dalam acara Musik Pantura, Selatan Malam (Senandung Tarling Malam), Selatan Siang (Senandung Tarling Siang), Laci (Lagu Cirebonan). Sesuai fungsi kontrol sosial dalam asas program interaktif, Cirebon TV memberi peluang kepada audience untuk berinteraksi dan berperan serta, baik langsung, maupun tidak langsung melalui SMS pada acara lipsus dan bincang-bincang. Penanggung jawab program siaran mengetahui tentang program Nawacita presiden yaitu: berdaulat politik, mandiri dalam ekonomi, berkepribadian dalam budaya.

Pemahaman tentang program revolusi mental pemerintah sebagai Nawacita kesembilan penguatan kekuatan budaya lokal dalam kebhinnekaan. Dampak diseminasi program revolusi mental bila disosialisasikan melalui stasiun televisi lokal bisa langsung dipahami masyarakat lokal karena penyampaian disampaikan dengan nilai-nilai tradisi lokal. Cirebon TV sebagai media diseminasi informasi program revolusi mental bisa bermanfaat menjalin komunikasi terbuka dan demokratis dengan menyajikan program siaran yang edukatif, inspiratif dan menghibur untuk mencerdaskan masyarakat lokal. Sosialisasi program revolusi mental melalui siaran televisi lokal dianggap efektif karena disampaikan dan dikemas dalam acara yang disukai masyarakat. Sangat efisien dibanding dengan sosialisasi melalui pertemuan, karena melalui siaran biaya relatif lebih sedikit jangkauan pemirsa lebih banyak, materi disampaikan dengan bahasa yang mudah dipahami masyarakat lokal.

Pemilik Cirebon TV memandang bahwa program revolusi mental dipandang dari sudut praktisi media televisi lokal dapat disosialisasikan dengan strategi menyusun ide, konsep, dan merealisasikan dengan bentuk acara yang ada. Program revolusi mental dijadikan prioritas sosialisasi melalui media televisi dengan panduan materi sosialisasi, serta alokasi dana sosialisasi yang proporsional untuk biaya produksi siaran. Mempertegas komitmen dan memberikan arahan serta pengertian stasiun televisi lokal agar bisa merealisasikan serta menyinergikan dengan program yang ada.

Menyosialisasikan program revolusi mental di stasiun televisi lokal diperlukan keahlian khusus dan keseragaman materi yang disajikan walaupun acaranya dikemas dalam konten lokal yang berbeda. Diperlukan kerjasama dan bantuan dana kegiatan dari pihak lain seperti Kemkominfo RI, KPI/KPID, Diskominfo, Humas, karena instansi-instansi yang terkait dan kompeten dalam mencerdaskan masyarakat menuju masyarakat informasi. Selama ini tidak ada kerjasama antara stasiun televisi lokal dengan pemerintah pusat/ daerah/ kementerian secara program atau finansial dalam menyosialisasikan program revolusi mental. Sosialisasi program revolusi mental melalui televisi lokal perlu dirancang secara matang, disiapkan seperti zaman Departemen Penerangan RI dulu. Program revolusi mental melalui media televisi lokal perlu dijadikan kebijakan untuk wajib siar.

Penanggungjawab program siaran Cirebon TV menyatakan bahwa dalam menyosialisasikan program revolusi mental, Kementerian Komunikasi dan Informatika (Kemkominfo) RI harus menjadi garda terdepan dalam menyiapkan materi siaran, materi siaran tinggal di putar dalam bentuk layanan masyarakat. Komisi Penyiaran Indonesia (KPI) dan Komisi Penyiaran Indonesia Daerah (KPID) sebagai kepanjangan pemerintah, memberi keleluasaan dalam inovasi tayangan dalam bentuk, berita, drama, atau talkshow yang menyentuh kepentingan tradisional. Fungsi pengelola program siaran televisi lokal dalam berpartisipasi menyosialisasikan program revolusi mental bisa berperan melalui kemasan program acara yang tradisional dengan mengadaptasi dan mengangkat potensi yang ada. 


\section{TV Kuningan}

Pemilik TV Kuningan adalah Emon Surahman, SE, beralamat di Dusun Manis Desa/Kec. Kadugede, Kab. Kuningan. Stasiun TV Kuningan berbadan hukum Lembaga Penyiaran Publik Lokal dengan nama di udara TV Kuningan. Memiliki frekuensi 27 UHF, No. IPP masih dalam proses. Alamat Stasiun TV Kuningan berada di Jl. Aruji Kartawinata No. 03, Kuningan 45511, Nomor Telepon: (0232) 8894507, E-mail: LPPLKng@gmail.com. TV Kuningan bekerjasama dengan TV Kabel dengan wilayah/jangkauan siaran di area Kuningan, sebagian Cirebon, sebagian Majalengka, dan sebagian daerah Jawa Tengah. TV Kuningan memiliki jumlah karyawan 8 orang.

\section{Kontribusi Kuningan TV dalam Menyosialisasikan Program Revolusi Mental}

Latar belakang mendirikan stasiun televisi lokal karena di Kabupaten Kuningan belum ada TV lokal sehingga belum terakomodirnya informasi-informasi lokal dan budaya lokal, sementara banyak potensi masyarakat yang belum terekspos media. Motivasi saat mendirikan stasiun televisi lokal adalah ingin memberikan pemerataan informasi daerah, dan menjalin komunikasi yang lebih interaktif dengan masyarakat Kuningan khususnya dan masyarakat sekitar Kuningan umumnya. Motivasi saat ini yaitu ingin mengangkat potensi lokal yang diangkat dalam siaran.

Historis keikutsertaan dalam stasiun televisi lokal karena pernah menjadi penyiar dan ditunjuk oleh Pemda Kuningan. Manfaat keberadaan stasiun televisi lokal bagi masyarakat yaitu antara lain: (a) Manfaat hiburan, penonton bisa menikmati hiburan daerah yang tidak disiarkan oleh televisi lain; (b) Manfaat pendidikan, penonton bisa menyaksikan siswa-siswi daerah sendiri tampil di TV milik masyarakat. Juga bisa menambah pengetahuan ilmu yang berguna, dan bisa memberikan wawasan pengetahuan global; (c) Manfaat diseminasi informasi, bisa memberikan pengetahuan yang baru dan bermanfaat bagi masyarakat; (d) Manfaat kontrol sosial, memberikan kritikan ke Pemda, meskipun TV ini milik Pemda.

Pemilik TV Kuningan memahami Nawacita pemerintah (presiden) merupakan arahan menuju kedaulatan politik, kemandirian ekonomi dan kepribadian memelihara budaya sendiri, melalui tindakan kebijakan dan implementasi kegiatan di lingkungan masing-masing baik di pemerintahan atau lembaga dan instansi lainnya. Sebagai lembaga yang bergerak di bidang penyiaran lebih membuka dialog baik kepada pemerintah maupun masyarakat yang dikemas dalam siaran atau kegiatan lainnya. Kearifan lokal dipahami sebagai nilai-nilai lokal yang sudah menjadi tradisi dalam berbagai aspek kehidupan, khususnya aspek budaya, begitu juga dengan perilaku, karena budaya dan perilaku masyarakat Kuningan mempunyai tata cara yang berbeda dengan komunitas lainnya.

Kontribusi Kuningan TV sebagai media diseminasi informasi tentang program revolusi mental merupakan salah satu ruang yang dapat dimanfaatkan menyosialisasikan mulai program siaran. Walaupun belum mempunyai kebijakan untuk mengarahkan, Kuningan TV menyosialisasikan program revolusi mental. Namun terdapat kebijakan yang dilakukan yaitu arahan dalam salah satu acara diselipkan materi untuk menyosialisasikan program revolusi mental. Hal ini disebabkan karena memiliki kedekatan dengan komunitasnya dan mudah untuk dipahami karena disesuaikan dengan keadaan lokal, misalnya dalam acara Saba Desa, efisien karena biaya lebih bisa dihemat, karena bisa diputar berulang-ulang.

Penanggungjawab program siaran TV Kuningan, M. Samsudin, menyosialisasikan program Nawacita presiden (pemerintah) dipahami dengan penyusun program yang memuat unsur penguatan budaya lokal dalam kebhinnekaan. Pemahaman tentang kearifan lokal sebagai tradisi yang terus menerus dipelihara dan dikembangkan dalam berbagai aspek kehidupan terutama budaya yang ada di masyarakat lokal. Materi siaran yang dibuat mendukung program siaran revolusi mental bukan khusus dibuat untuk program siaran revolusi mental, tapi disisipkan dalam acara 
lain, seperti acara pagi Car Free Day, yang disiarkan secara live. Dampak diseminasi program revolusi mental bila disosialisasikan melalui stasiun televisi lokal akan bagus, karena masyarakat akan mengetahui dan memahami gerakan-gerakan yang dianjurkan oleh pemerintah sekarang.

Materi siaran berita seperti apa yang bisa menyajikan materi revolusi mental adalah siaran berita Infokus yang menyajikan info khusus, dikemas secara khusus dan mendalam tentang keadaan yang terjadi di Kabupaten Kuningan. Kontribusi stasiun televisi lokal dalam menyosialisasikan program revolusi mental memerlukan investasi khusus karena bagaimana dapat berjalan dengan baik, jika program tersebut tidak ada dananya. Kontribusi Kuningan TV sebagai media diseminasi informasi program revolusi mental sangat penting karena bisa mengubah masyarakat ke arah yang lebih bagus.

Masyarakat yang tadinya tidak mengetahui akan program revolusi mental, setelah menonton mereka jadi mengetahuinya. Sosialisasi program revolusi mental melalui televisi lokal efektif karena keberadaan TV lokal merupakan salah satu pilihan dari warga untuk menonton acara lokal yang disukai oleh masyarakat, serta dapat diulang-ulang acara tersebut, kapanpun diperlukan tayangan itu akan mudah untuk ditayangkan.

Pemilik Kuningan TV menyarankan kepada semua pihak baik pemerintah dalam hal pemerintah daerah c/q Diskominfo, Humas, Kemkominfo RI, serta lembaga KPI/KPID, program sosialisasi revolusi mental harus dijadikan prioritas sosialisasi melalui media televisi, perlu ada panduan materi sosialisasi, serta alokasi dana untuk biaya produksi siarannya. Perlu ada komitmen bersama dan memberikan arahan dan pengertian kepada manajer program acara agar bisa merealisasikan serta menyinergikan dengan program yang telah ada. Sosialisasi program revolusi mental di stasiun televisi lokal diperlukan materi untuk disajikan. Diperlukan kerjasama dengan pihak lain karena instansi-instansi yang terkait sangat kompeten dalam mencerdaskan masyarakat menuju masyarakat informasi.

Selama ini belum ada acara khusus tentang revolusi mental. Jika diprogramkan, tentu harus ada biaya khusus dari pemerintah pusat/ daerah, bantuan dari Kemkominfo, KPI/KPID, Diskominfo, Humas, dan Kementerian lainnya. Kerjasama antara stasiun televisi lokal dengan pemerintah pusat/daerah/kementerian secara program atau finansial dalam menyosialisasikan program revolusi mental, sampai saat ini tidak pernah dilakukan, kecuali iklan layanan masyarakat untuk program lain bukan revolusi mental. Sosialisasi program revolusi mental melalui media televisi lokal perlu dirancang matang agar dapat disiarkan di televisi nasional dan televisi lokal. Agar wacana sosialisasi revolusi mental melalui media siar perlu dijadikan kebijakan untuk wajib siar. Harapannya revolusi mental diagendakan untuk wajib siar apakah bentuk layanan masyarakat atau bentuk lainnya.

Penanggungjawab siaran menyarankan dalam menyosialisasikan program revolusi mental diharapkan Kemkominfo dapat memberikan arahan atau kebijakan. KPI/ KPID agar yang selama ini sudah ada kegiatan dengan televisi lokal yang berupa talkshow lebih ditingkatkan lagi.

Fungsi pengelola program siaran televisi lokal dalam berpartisipasi menyosialisasikan program revolusi mental dengan cara membuat acara yang dapat diselipkan oleh materi-materi menyosialisasikan program revolusi mental. Perlu keahlian khusus, karena tidak semua orang dapat mengerjakan program revolusi mental, hanya orang tertentu saja yang mempunyai keahlian khusus. Kerjasama dalam penyusunan program dan materi siaran, dalam upaya menyosialisasikan program revolusi mental di stasiun televisi lokal diperlukan biaya khusus dan kerjasama dengan pihak lain dalam bentuk program dan biaya pembuatan program acara.

\section{SMTV Sumedang}

Pemilik SMTV Sumedang adalah Asep Anang Supriatna, dengan alamat di Desa Cibeureum Wetan, RT 01/03, Kec. Cimalaka, 
Kab. Sumedang. Keanggotaan dalam profesi jurnalistik: Persatuan Jurnalis Indonesia (PJI). Nama stasiun televisi SMTV Sumedang adalah SMTV19, sedangkan nama badan hukumnya, yaitu: PT. Sumedang Televisi Utama (SMTV), nama di udara, "SMTV eces pisan". SMTV memiliki No. IPP NPWP: 31.288.865.4.446.00 22. Serta memiliki alamat di J1. Raya Sumedang-Cirebon 259, Mandala Herang, Cimalaka-Sumedang. SMTV memiliki frekuensi 29 UHF, dengan wilayah/jangkauan siaran di area Kab. Sumedang dan Majalengka. Keterkaitan dengan stasiun televisi nasional dengan Jawapos TV sebagai perusahaan induk grup, dan memiliki jumlah karyawan sebanyak 18 orang.

\section{Kontribusi SMTV Sumedang dalam Menyosialisasikan Program Revolusi Mental}

Latar belakang mendirikan stasiun televisi lokal karena pernah menjadi penyiar radio sehingga berkeinginan untuk mendirikan televisi lokal karena teknologi informasi sangat diperlukan sampai ke pelosok daerah. Motivasi saat mendirikan stasiun televisi lokal karena orang media yang sudah lama ingin meningkatkan informasi lokal bisa tersampaikan ke publik melalui TV lokal. Ingin memiliki kontribusi tentang budaya daerah melalui siaran televisi lokal sehingga terinspirasi untuk mendirikan televisi di daerah sendiri di Kabupaten Sumedang dengan nama televisi SMTV.

Pengetahuan atau pemahaman tentang Nawacita pemerintah masih hanya sebatas dari talkshow politik yang disiarkan pada televisi nasional saja seperti pada TVOne, Kompas TV, dan lain-lain. Pengetahuan atau pemahaman tentang program revolusi mental pemerintah (presiden) sebagai Nawacita ke sembilan masih belum dipublikasikan dan sepakat program tersebut bagus dan perlu untuk dipublikasikan.

Kearifan lokal menjadi lebih dominan untuk menghidupkan budaya lokal menjadi tugas SMTV Sumedang agar tidak bersaing dengan televisi nasional adalah budaya lokal. Di SMTV kebijakan yang resmi dibuat belum ada tapi untuk berkontribusi dalam menyosialisasikan program revolusi mental baru lewat program siaran kesenian budaya lokal saja. Kebijakan yang harus dibuat oleh Kemkominfo RI, pemerintah pusat dan daerah serta pihak terkait lainnya sehingga program revolusi mental dapat dilaksanakan melalui isi siaran program revoluasi mental pada televisi nasional maupun lokal.

Sosialisasi program revolusi mental melalui stasiun televisi lokal kurang efektif dan sebaiknya dibarengi dengan siaran televisi nasional agar program siaran tentang revolusi mental dapat diterima oleh seluruh masyarakat di berbagai wilayah. Tidak efektif apabila program siaran revolusi mental hanya dalam bentuk sosialisasi saja tidak dalam bentuk isi siaran yang berbentuk talkshow sehingga masyarakat dapat menonton dan melihat serta menyimak bagaimana sebenarnya program televisi yang berisi revolusi mental itu, serta durasinya sebaiknya agak lama yaitu sekitar satu jam.

Sosialisasi program revolusi mental melalui stasiun televisi lokal kurang efisien karena hanya melalui televisi lokal eksplorasi program siaran kurang dapat diterima oleh masyarakat luas sementara televisi lokal mempunyai batas wilayah siaran sehingga program siaran revolusi mental hanya bisa diterima oleh masyarakat di wilayah tertentu. Program revolusi mental bisa disiarkan melalui program talkshow dengan program siaran televisi lain.

Menyosialisasikan program revolusi mental dipandang dari sudut praktisi media televisi lokal dianggap cukup baik apalagi program ini dipandang perlu disiarkan sehingga pola siaran tentang ketentuan yang mengatur perilaku dan mendorong kinerja baik karyawan. Kemkominfo RI bisa berperan aktif dan efektif melalui Kelompok Informasi Masyarakat (KIM), lalu untuk KPI berperan sebagai pengawas dalam bidang isi siaran TV atau dengan kata lain KPI sebagai pengawas konten isi siaran. Fungsi dan peran pemilik stasiun televisi lokal dalam berpartisipasi menyosialisasikan program revolusi mental yaitu ikut mendorong pemahaman tentang revolusi mental dengan membuat program-program siaran yang 
edukatif dalam mendorong program revolusi mental.

Dalam upaya menyosialisasikan program revolusi mental, stasiun televisi lokal memerlukan kerjasama dengan pihak lain seperti Kemkominfo, KPI/KPID, Diskominfo, Humas, karena dianggap kebijakan pemerintah harus jelas bisa disampaikan oleh pihak berwenang. Bantuan tentu sangat diperlukan baik dari Kemkominfo RI dari segi bantuan peralatan, dari KPI/KPID dari sisi pengawasan program isi siarannya, Diskominfo dapat berkerjasama dengan dinas lain dan Humas dapat bekerja sama dengan instansi lain baik dengan pemerintah daerah maupun dengan pemegang budaya seni budaya. Sampai saat ini belum ada kerjasama atau bantuan, pemerintah belum memberikan sosialisasi kepada TV Lokal tentang program siaran televisi lokal.

Tentang manfaat penelitian Kontribusi Media Televisi Lokal Dalam Menyosialisasikan Program Revolusi Mental yang sedang dilaksanakan, dapat melihat media TV lokal dalam mendorong program ini. Dampaknya mudah-mudahan dari TV yang tidak mendukung bisa mendukung dan mengundang tokoh seperti Kabiro Humas dengan inisiatif sendiri.

Penanggungjawab program siaran SMTV Sumedang belum mengikuti tentang Nawacita dan revolusi mental pemerintah. Tentang kearifan lokal, budaya lokal di Sumedang banyak seniman dan budayawan yang sampai saat ini belum sejahtera. Minat kaum muda untuk budaya lokal masih kurang dengan adanya TV lokal akhirnya mereka mau belajar dan mengembangkan budaya lokal. Materi siaran yang dibuat mendukung program siaran revolusi mental secara tidak langsung sudah ada apakah itu sesuai atau tidak dengan Nawacita tapi kriterianya ada. Program Untukmu Sumedang dengan durasi $1 / 2$ jam dan talkshow $1 / 2$ jam, mengangkat tema pembangunan yang dimulai dari diri sendiri. Mereka usaha sendiri bikin dulu acara, program dan lain-lain. Revolusi mental bisa namun harus punya motivasi sendiri untuk memajukan daerah Sumedang.

Bentuk keterlibatan yang bisa dilakukan oleh SMTV Sumedang sebagai stasiun televisi lokal dalam upaya menyosialisasikan program revolusi mental di antaranya membuat upaya ekonomi masyarakat. Masyarakat belum paham tentang revolusi mental. Kontribusi stasiun televisi lokal dalam menyosialisasikan program revolusi mental memerlukan investasi khusus terutama finansial dan SDM karena semua itu memerlukan biaya.

Peran TV lokal sangat berpengaruh terhadap keadaan masyarakat saat ini dengan program pemerintah sekarang. Keberadaan televisi lokal dalam menyosialisasikan program revolusi mental sangat baik sehingga mudah diterima dan sampai ke masyarakat langsung karena daya jangkau TV lokal untuk Sumedang dan Majalengka memang saat ini masyarakat mulai menikmati program siaran TV lokal.

Dalam menyosialisasikan program revolusi mental dipandang dari sudut pembuat program siaran media televisi lokal sangat diperlukan terutama dalam pertukaran program siaran berupa seminar, talkshow di TV pelayanan masyarakat. Berkaitan dengan sosialisasi program revolusi mental yang sedang dilaksanakan terhadap eksistensi stasiun televisi lokal, terhadap tercapainya diseminasi informasi program pemerintah, dan dampak terhadap masyarakat, dampaknya bagus dan sangat mendukung program revolusi mental tersebut.

\section{Pembahasan}

Melihat fungsi dan kemampuan yang dimilikinya, stasiun televisi lokal sebagai sumber informasi yang diakses publik menjadi salah satu pilar yang bisa mendukung program revolusi mental melalui penyebaran informasi tentang apa yang akan dilakukan dan yang telah dilaksanakan pemerintah. Stasiun televisi lokal dapat berkontribusi melakukan rekonstruksi pada lingkungan lokalnya, dapat berperan menjadi jembatan informasi dan bisa menumbuhkan partisipasi nyata dari masyarakat untuk melakukan revolusi mental, menciptakan paradigma, budaya politik, dan pendekatan nation building baru yang lebih manusiawi, sesuai dengan budaya nusantara, bersahaja, dan 
berkesinambungan seperti yang diamanatkan oleh presiden.

Peran stasiun televisi lokal sebagai akses informasi publik sangat menentukan dalam menyosialisasikan program revolusi mental pemerintah.

Media massa merupakan media diseminasi informasi dalam bentuk karya jurnalistik dalam mempercepat proses perubahan sosial. Stasiun televisi lokal bisa berperan sebagai sumber rujukan penyebaran informasi yang cepat. Dalam hal ini, media dapat meningkatkan tingkat pengetahuan masyarakat.

Pemilik stasiun televisi lokal sesuai dengan posisinya mempunyai kemampuan manajerial pengelolaan stasiun televisi. Pemilik stasiun televisi lokal tidak secara formal mempunyai pendidikan teknis tentang jurnalistik dan media massa. Pemilik stasiun televisi lokal masuk dalam keanggotan dalam organisasi pengelolaan televisi seperti asosiasi TV lokal, namun tidak menjadi anggota dalam profesi jurnalistik. Stasiun televisi lokal telah memiliki No. IPP yang dikeluarkan oleh Kementerian Komunikasi dan Informatika (Kemenkominfo) Republik Indonesia. Mempergunakan channel UHF dengan jangkauan meliputi 3 - 4 kabupaten di sekitarnya.

Latar belakang mendirikan stasiun televisi lokal karena belum terakomodirnya informasi-informasi lokal dan budaya lokal pada stasiun televisi nasional, sementara banyak potensi masyarakat yang belum terekspose media. Motivasi mendirikan stasiun televisi lokal karena ingin memberikan pemerataan informasi, dan menjalin komunikasi yang lebih interaktif dengan masyarakat, ingin mengangkat potensi lokal yang diangkat dalam siaran stasiun televisi lokal secara terus menata program siaran yang dapat mendekatkan masyarakat dan pemerintah, masyarakat dan masyarakat. Diantaranya telah mendapatkan Penghargaan Kategori "Budaya Tradisi" dari KPID Provinsi Jawa Barat.

Modal investasi awal (modal kapital, SDM, infrastruktur) diantara Rp. 500.000 .000 dan tidak melibatkan penyertaan modal dari pihak lain. Sebagai pemilik, terlibat langsung mengelola bahkan dibantu keluarga sesuai kompetensi ilmu yang dimiliki. Program siaran mengambil jasa profesional yang berlatar belakang jurnalis. Menempatkan orang-orang yang memahami teknologi, dan orang orang yang memahami jurnalistik dan budaya. Menempatkan personil yang mengerti keuangan dan pembukuan dan memercayai staf untuk melakukan kontrol. Menempatkan personil yang mengerti administrasi perkantoran dan kesekretariatan, serta menempatkan personil yang memahami jurnalisme media.

Pemilik stasiun televisi lokal telah mengetahui dan memahami tentang Nawacita pemerintah merupakan arahan menuju kedaulatan politik, kemandirian ekonomi, dan kepribadian memelihara budaya sendiri, melalui tindakan kebijakan dan implementasi kegiatan di lingkungan masing-masing baik di pemerintahan atau lembaga dan instuisi lainnya.

Stasiun televisi lokal dapat ikut serta berkontribusi menyosialisasikan program revolusi mental yang dikemas dalam siaran atau kegiatan lainnya. Dicontohkan kalau dulu mental itu dibentuk melaui tahapan penataran P4, untuk pemahaman ideologi Pancasila, sekarang bagus sudah dilaksanakan melalui program revolusi mental. Pemilik stasiun televisi lokal memahami kearifan lokal sebagai nilai-nilai lokal yang sudah menjadi tradisi dalam berbagai aspek kehidupan, khususnya aspek budaya, karena masyarakat mempunyai tatacara dan berbeda dengan masyarakat di daerah lainnya yang merupakan kekayaan budaya bangsa.

Dalam konteks sosialisasi revolusi mental, terutama bangsa yang punya harga diri dan percaya diri akan kekayaan jati dirinya, televisi lokal merupakan salah satu ruang yang dapat dimanfaatkan menyosialisasikan mulai program siaran. Kebijakan yang mengarahkan stasiun televisi yang dikelola melalui program siaran untuk berkontribusi menyosialisasikan program revolusi mental kebijakan untuk berkontribusi menyosialisasikan revolusi mental agar disinergikan dengan asas program siaran dan jadwal acara siaran televisi lokal. 
Kebijakan yang dilakukan yang dituangkan dalam salah satu asas program yaitu reality, yang isi dan kemasan program mengutamakan bahan baku yang bersumber dari realitas kehidupan sehari-hari, untuk mewujudkan sosialisasi revolusi mental bisa di program acara unggulan, yaitu talkshow bincang-bincang (b2) dan liputan khusus (lipsus).

Siaran stasiun televisi lokal dianggap efektif dalam menyosialisasikan program revolusi mental karena memiliki kedekatan dengan komunitasnya, menghadirkan tokoh dari kalangan masyarakat maupun eksekutif yang jadi panutan masyarakat. Sosialisasi program revolusi mental melalui siaran stasiun televisi lokal dianggap sangat efektif karena pemerintah tidak perlu mengalokasi dana konsumsi atau gedung pertemuan untuk menghadirakan orang namun dengan jangkauan yang terbatas, tetapi cukup mengalokasikan dana untuk membayar durasi biaya produksi siaran. Sesuai dengan fungsi media massa, siaran stasiun televisi lokal dalam konteks media sosialisasi program revolusi mental, dikemas dalam segmen hiburan, pendidikan, informatif, dan media sosial kontrol.

Pengelola stasiun televisi lokal mengharapkan Kemenkominfo RI menjadi penyedia materi siaran atau bentuk layanan informasi lainnya KPI Daerah Provinsi Jawa Barat sebagai mitra pemerintah, memberi keleluasaan dalam inovasi tayangan dalam bentuk, berita, drama, atau talkshow yang menyentuh kepentingan tradisional. Sosialisasi program revolusi mental di stasiun televisi lokal diperlukan keahlian khusus untuk mengadaptasi atau mengangkat potensi yang ada. Dari hasil penelitian maka dapat digambarkan model penyebaran informasi dan model kemitraan antara pemerintah dengan pengelola stasiun televisi lokal disajikan dalam Gambar 1 dan Gambar 2.

Kontribusi televisi lokal melalui program siarannya dapat menimbulkan efek besar terhadap masyarakat luas dan memiliki peran penting dalam proses pemeliharaan, perubahan, dan penyampaian program pemerintah, diantaranya tentang revolusi mental.

Kontribusi yang bisa diberikan oleh televisi lokal dalam menyosialisasikan program revolusi mental sebagai efek kognitif adalah berkontribusi dalam menyebarluaskan atau diseminasi informasi, membentuk sikap, menumbuhkan keyakinan masyarakat terhadap program revolusi mental. Kontribusi afektif media televisi lokal dalam menyosialisasikan program revolusi mental adalah meningkatkan meningkatkan dukungan moral masyarakat terhadap pemerintah. Kontribusi media televisi lokal secara behavioral adalah efek yang mampu yang didasarkan kepada penyediaan dan penyebaran informasi dalam menyosialisasikan program revolusi mental pemerintah.

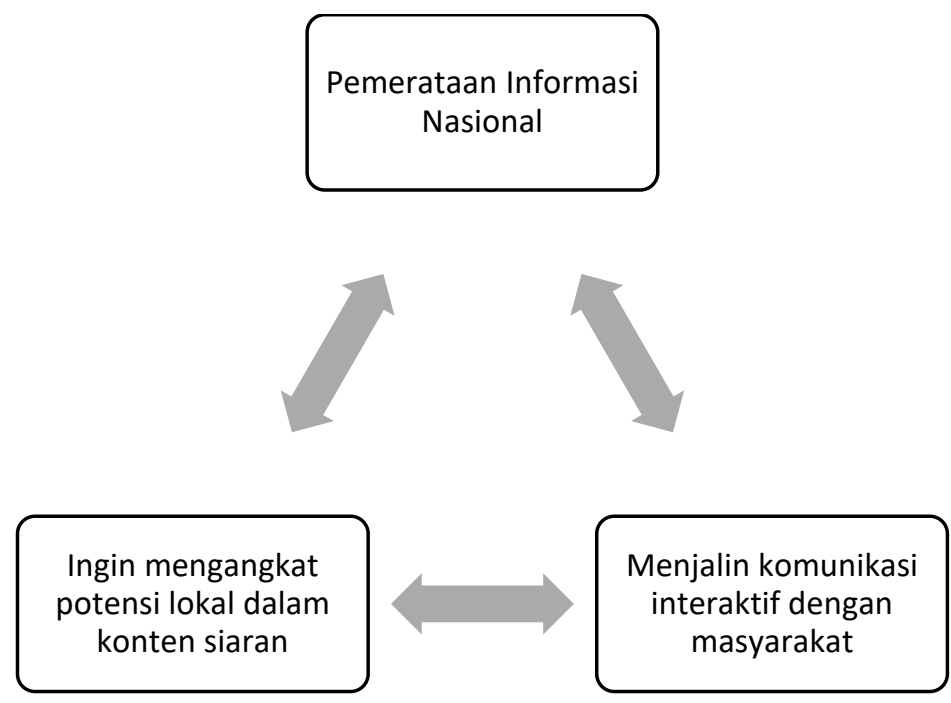

Gambar 1. Model penyebaran informasi . 


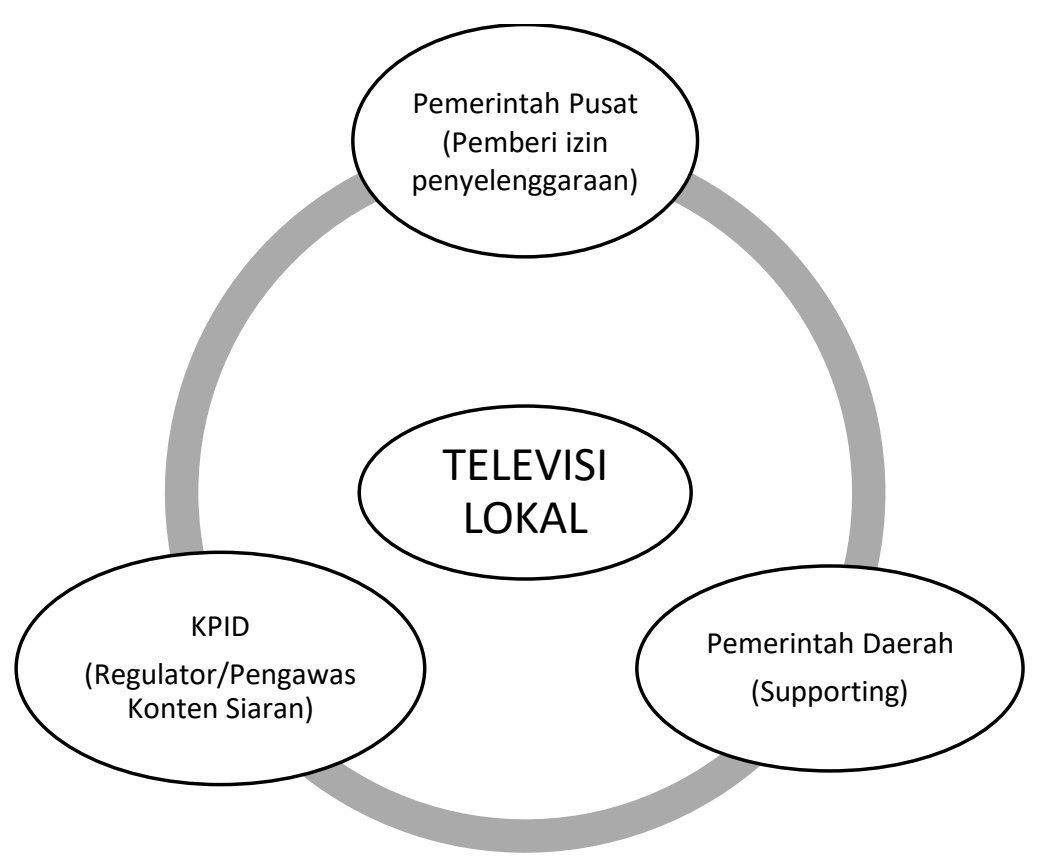

Gambar 2. Model Kemitraan Pemerintah dengan stasiun televisi lokal

Selain sebagai media penyampaian informasi, televisi lokal merupakan media komunikasi timbal balik antara masyarakat dan pemerintah. Terkait berbagai kebijakan dan program.

\section{PENUTUP}

\section{Simpulan}

Stasiun televisi lokal secara langsung atau tidak langsung telah berkontribusi menyosialisasikan program revolusi mental melalui program siaran yang dibuat. Melibatkan dirinya dalam mengangkat budaya dan kearifan lokal di lingkungannya, baik berupa penyediaan konten siaran, pendanaan, yang pada gilirannya berdampak kepada upaya menyosialisasikan revolusi mental sebagaimana yang diprogramkan oleh pemerintah.

Kontribusi siaran televisi lokal efektif dan efisien untuk berperan sebagai media sosialisasi sesuai dengan fungsi yang dimilikinya. Program revolusi mental dapat dikemas dengan menyediakan informasi positif dan seimbang. Fungsi pendidikan dikemas dengan landasan misi menjalin komunikasi terbuka dan demokratis, setiap acara disajikan dengan nuansa edukatif, inspiratif, disajikan dalam konten lokal yang variatif.

Program revolusi mental telah disosialisasikan melalui materi acara sosial, pendidikan, hiburan dengan inovatif berbasis kearifan lokal. Revolusi mental dapat disosialisasikan melalui semua fungsi yang dimiliki media televisi. Sesuai fungsi hiburan sosialisasi program revolusi mental dikemas dalam segmentasi hiburan, budaya dan informasi. Sesuai fungsi kontrol sosial, revolusi mental dapat dilakukan melalui program siaran interaktif yang memberi peluang kepada audiens untuk berinteraksi dan berperan serta, baik langsung, maupun tidak langsung melalui SMS pada acara lipsus dan bincang bincang.

Revolusi mental telah dilakukan dan dieksplorasi pada stasiun televisi lokal yang dibuat berdasarkan pemikiran dan sudut pandang lokal yang variatif dan inovatif. Walaupun tidak secara langsung program yang dibuat secara spesifik adalah diseminasi program revolusi mental yang berimplikasi terhadap penyiapan finansial. Stasiun televisi lokal telah berkontribusi sesuai kompetensi dan kemampuan sarana dan prasarana yang dimilikinya. Stasiun televisi lokal dapat memberikan pengetahuan, pemahaman, menimbulkan reaksi positif tentang progaram revolusi mental dan Nawacita. Peran media 
massa sebagai akses informasi publik sangatlah penting karena masyarakat membutuhkan referensi.

\section{Saran}

Perlu adanya program sosialisasi yang terstruktur dari pemerintah pusat dan daerah yang memberikan pengetahuan, pemahaman tentang program revolusi mental khususnya kepada para pengelola stasiun televisi lokal.

Perlu adanya model kerjasama kemitraan dari pemerintah pusat dan pemerintah daerah dengan pengelola stasiun televisi lokal dalam menyosialisasikan program revolusi mental. Model kerjasama diantaranya dalam hal konten, pendanaan/finansial, dan sasaran yang ingin diperoleh.

\section{DAFTAR PUSTAKA}

Ardianto, E., Komala, L. \& Karlinah, S. (2004) Komunikasi Massa: Suatu Pengantar. Bandung, Simbiosa Rekatama Media.

Kementerian Komunikasi dan Informatika (2015) RENCANA STRATEGIS KEMENTERIAN KOMUNIKASI DAN INFORMATIKA TAHUN 2015-2019. [Online]. Available from:

http://web.kominfo.go.id/sites/default/files/u sers/12/PM Kominfo No.22 Th 2015 Renstra Kominfo 2015--2019_Final.pdf. Sobur, A. (2002) Analisis Teks Media Suatu Analisis untuk Analisis Wacana, Analisis Semiotik, dan Framing. Bandung, Remaja Rosdakarya.

Subiakto, H. \& Ida, R. (2012) Komunikasi Politik, Media dan Demokrasi. Jakarta, Kencana Prenada Media Group.

Sumadiria, A.H. (2005) Jurnalistik Indonesia: Menulis Berita dan Feature. Bandung, Simbiosa Rekatama Media.

Suprastowo, P. (2014) Kontribusi Bantuan Siswa Miskin Terhadap Keberlangsungan dan Keberlanjutan Pendidikan Siswa. Jurnal Pendidikan dan Kebudayaan. [Online] 20 (2), 149-172. Available from: http://download.portalgaruda.org/article.php ?article $=465561 \& \mathrm{val}=9630 \&$ title $=$ KONTRI BUSI BANTUAN SISWA MISKIN TERHADAP KEBERLANGSUNGAN DAN KEBERLANJUTAN PENDIDIKAN SISWA.

Wedhaswary, I.D. (2015) 'Nawa Cita', 9 Agenda Prioritas Jokowi-JK. [Online]. 2015.

Available from: http://nasional.kompas.com/read/2014/05/21 /0754454/.Nawa.Cita.9.Agenda.Prioritas.Jok owi-JK [Accessed: 5 August 2015]. 